\title{
References
}

Barnett, M. (2011) Empire of Humanity. A History of Humanitarianism. Cornell University Press.

Brada, B. (2016) The Contingency of Humanitarianism: Moral Authority in an African HIV Clinic. American Anthropologist, 118(4): 755-771.

Gilbert, A. (2016) From Humanitarianism to Humanitarianization: Intimacy, Estrangement, and International Aid in Postwar Bosnia and Herzegovina. American Ethnologist, 43(4): 717-729.

Minear, L. (2002) The Humanitarian Enterprise. Dilemmas and Discoveries. Kumarian Press.

Plattner, D. (1996) ICRC Neutrality and Neutrality in Humanitarian Assistance. International Review of the Red Cross. 311: 161-179.

Redfield, P. (2010) The Impossible Problem of Neutrality. In: Bornstein, E., Redfield, P. eds. Forces of Compassion. Humanitarianism Between Ethics and Politics. School for Advanced Research Press.

Terry, F. (2001) The Principle of Neutrality: Is It Relevant to Msf? Les Cahiers de Messages, 113: 1-5.

Terry, F. (2002) Condemned to Repeat? The Paradox of Humanitarian Action. Cornell University Press.

\section{Non-governmental Organizations}

Non-governmental organizations (NGOs) are crucial actors in the humanitarian field. However, there are differences between NGOs and other humanitarian actors in terms of origin and status. Humanitarianism is mostly understood as emergency relief for vulnerable and suffering people. The International Committee of the Red Cross (ICRC), created in 1863 after the massacre at the Battle of Solferino (1859), constitutes the core of modern humanitarian intervention. It was recognized as a transnational humanitarian organization by the Geneva Conventions in 1949. NGOs, instead, are generally seen as promoters of social change, even though there is no internationally agreed definition of them (Ryfman 2007). Anti-Slavery International, created in 1839 and inspired by a Christian attitude against slavery, is often mentioned as the first international NGO, although the term "non-governmental organization" was introduced later, in 1945 with Article 71 of the United Nations (UN) Charter. A variety of different organizations have been established since the end of World War II and the 
process of decolonization that triggered international development as a global phenomenon (Krause 2014). In the 1980s, a boost in the sector led to a global rise of NGOs, including a number of faith-based organizations (Christian, Islamic, Buddhist, etc.) who got involved in delivering humanitarian aid (Ferris 2005). Since that time, these actors have brought new approaches, but also new problems, especially following the "War on Terror" and the overpoliticized relationship between Christian and Muslim organizations (Ryfman 2007).

Jude Howell and Jeremy Lind (2009) distinguish between the roles of NGOS as actors and agents. As actors, NGOs promote certain values. At the same time, they work as agents of social cohesion and stability. In the relationship with humanitarianism, both aspects are relevant. Yet NGOs do not represent a homogeneous body of organizations, which may differ significantly in terms of ideals and actions. While the creation of Médecins Sans Frontières (MSF) in 1971 was an open critique of the ICRC approach to the Biafra crisis and inaugurated a new course of actions to address humanitarian crises, the UN Development Programme and other UN agencies have since the 1970s increased their cooperation with NGOS, who progressively assumed the role of services providers in the humanitarian field. Organizations such as Oxfam, CARE, or Action Contre la Faim became important humanitarian actors, and their involvement was connected to standards and procedures set by the donors, rather than by the critical and independent approach promoted by MSF (Krause 2014). These organizations deal with various aspects of emergency aid in different sectors, and their role has increased since the 1980 .

NGOs connect humanitarian and development interventions, for instance through the discourse of human rights. Moreover, global neoliberal reforms in the post-Cold War era have reduced the intervention of the state in welfare provision, delegating this role to NGOS. However, as they are not recognized under international law, the nature of their legitimacy is often contested. Howell and Lind (2009: 30) note that "the relationship between NGOs and international institutions such as the International Monetary Fund and the World Bank was fraught with tension and mutual suspicion," putting the roles and legitimacy of NGOs under more scrutiny.

Janice Gross Stein (2008) emphasizes the double nature of NGOs' accountability, toward representativeness and effectiveness. NGOS should both prove capable of guaranteeing a certain standard of intervention and also of representing the needs and interest of their stakeholders to win legitimacy at the international level. While an organization such as the ICRC has a recognized code and procedures that can be applied in every humanitarian context, most 
of the NGOs' legitimacy comes from their connection to their stakeholders and beneficiaries. Philippe Ryfman (2007) underlines this tension between standardized procedures required by donors, such as the European Civil Protection and Humanitarian Aid Operations or the UN, and the need to be accountable to a grassroots base inspired by specific values.

The growing importance of humanitarian budgets has pushed NGOs onto a path of standardization and professionalization. There are initiatives aimed at supporting this tendency, such as the Sphere project, launched in 1996 to create a common set of humanitarian standards, and the Humanitarian Accountability Project, which aimed to create a standard procedure to make NGOs accountable toward their beneficiaries. Monica Krause (2014) relates both these initiatives to what she defines as the "market for project" approach, which sees NGOs competing for funding in the production of projects evaluated by donors. This competition is pushing NGOs to enlarge their field of action, for example by increasing their roles in the security and state-building sectors. This was evident in the "War on Terror" in Afghanistan and Iraq and, more recently, in the fight against Boko Haram in the Sahel. Moreover, humanitarian agencies count on the capacity of NGOs to mobilize funding through their stakeholders, examples being after the earthquakes in the Indian Ocean in 2004 and in Haiti in 2010. According to Howell and Lind (2009), this blurs the borders between humanitarian and military actors, and between NGOs and state actors.

\section{Valerio Colosio}

\section{References}

Ferris, E. (2005) Faith-Based and Secular Humanitarian Organizations. International Review of the Red Cross, $87(858)$ : 311-325.

Howell, J., Lind, J. (2009) Theorising the Securitisation of Aid and Effects on Civil Societies. In: Counter-Terrorism, Aid and Civil Society. Palgrave Macmillan.

Krause, M. (2014) The Good Project: Humanitarian Relief NGos and the Fragmentation of Reason. University of Chicago Press.

Ryfman, P. (2007) Non-Governmental Organizations: An Indispensable Player of $\mathrm{Hu}-$ manitarian Aid. International Review of the Red Cross, 89(865): 21-46.

Stein, J. (2008) Humanitarian Organizations. Accountable-Why, to Whom, for What and How? In: Barnett, M., Weiss, T.G. eds. Humanitarianism in Question: Politics, Power, Ethics. Cornell University Press. 